\title{
After the Critique of Rights: For a Radical Democratic Theory and Practice of Human Rights
}

\author{
Kathryn McNeilly ${ }^{1}$
}

Published online: 11 July 2016

(C) The Author(s) 2016. This article is published with open access at Springerlink.com

\begin{abstract}
The critique of human rights has proliferated in critical legal thinking over recent years, making it clear that we can no longer uncritically approach human rights in their liberal form. In this article I assert that after the critique of rights one way human rights may be productively re-engaged in radical politics is by drawing from the radical democratic tradition. Radical democratic thought provides plausible resources to rework the shortcomings of liberal human rights, and allows human rights to be brought within the purview of a wider political project adopting a critical approach to current relations of power. Building upon previous re-engagements with rights using radical democratic thought, I return to the work of Ernesto Laclau and Chantal Mouffe to explore how human rights may be thought as an antagonistic hegemonic activity within a critical relation to power, a concept which is fundamentally futural, and may emerge as one site for work towards radical and plural democracy. I also assert, via Judith Butler's model of cultural translation, that a radical democratic practice of human rights may be advanced which resonates with and builds upon already existing activism, thereby holding possibilities to persuade those who remain sceptical as to radical re-engagements with rights.
\end{abstract}

Keywords Human rights · Radical democracy · Ernesto Laclau and Chantal Mouffe $\cdot$ Cultural translation · Judith Butler

Kathryn McNeilly

k.mcneilly@qub.ac.uk

1 School of Law, Queen's University Belfast, 28 University Square, Belfast BT7 1NN, UK 


\section{Introduction}

Critical engagements with human rights have dominated much of critical legal thought throughout the past number of years. The conclusion appears to have been reached, albeit not always by the same means, that we can no longer uncritically accept human rights in their current, liberal form. What follows from this conclusion, however, is more contested. What can we do with human rights after critique? How do we approach rights when we no longer worship at their altar? One proposal is that after the critique of human rights it may be possible to reclaim their potential for radical politics by using radical democratic thought. In this article I advance that such thought is of use because it provides plausible resources to address the shortcomings of human rights within liberalism, and allows human rights to be brought within the purview of a wider political project adopting a critical approach to current relations of power. In doing so I return to the work of Ernesto Laclau and Chantal Mouffe to build upon already existing accounts of rights in radical democratic terms and assert that their work can be productively employed to reimagine human rights as a site for antagonistic hegemonic activity to challenge regimes of power and as ideals which are fundamentally futural, drawing us into a never-ending striving for them within the wider context of work for radical and plural democracy. However, the productive possibilities that radical democratic thought offers re-engagements with human rights do not end with theoretical reengagements. I assert that radical democratic resources can also be drawn upon to productively think through a more radical practice of human rights.

In fleshing out more of what it might mean to imagine a radical democratic practice of human rights I propose that the model of cultural translation found in the work of Judith Butler can be developed as a bridge to link the theorisation of human rights beyond liberalism using radical democratic resources with the contemporary politics and practice of human rights. A concept with palpably radical democratic underpinnings, cultural translation allows the tenets of Laclau and Mouffe's radical democratic thought to be brought to bear on human rights practice. Cultural translation is advanced as useful in providing a lens through which human rights may be re-read and a framework to direct engagement in human rights politics. Indeed, foundations of such an approach can already be detected in contemporary human rights activism. What cultural translation offers, therefore, is potential for activists to consciously think through their practice as one of cultural translation and link it to a wider project for radical democracy. Use of cultural translation in this way seeks to address scholars and commentators who remain sceptical as to the possibility to radically re-engage human rights; offering a persuasive way to facilitate a radical practice of human rights which stems from radical democratic theoretical resources addressing the limitations of liberal human rights and also has clear resonances with contemporary activism. Accordingly, the possibilities which radical democratic thought offers to radically re-engage human rights after their critique are furthered through engagement with cultural translation which helps advance a persuasive radical democratic practice of human rights. 


\section{Liberal Human Rights: Critique}

Human rights have a long pedigree within liberalism and liberal thinking, stemming in their development from the work of sixteenth- and seventeenth-century liberal and natural law theorists such as Hobbes and Locke (Shapiro 1989, pp. 80-150; Moyn 2012, pp. 21-24). By virtue of this pedigree human rights enshrine liberal protection of the individual from oppressive state interference, and foreground a particularly liberal approach to personhood. The subject of liberal human rights is a bounded individual who possesses their life, liberty and security as property which should be protected from external interference, in doing so reflecting the wider imperatives of a capitalist economy (MacPherson 1962, pp. 2-4). Critical engagements with human rights have highlighted the way in which such a perception of liberal subjectivity enshrined within human rights forecloses wider relations of intersubjectivity and embodiment which characterise our existence as subjects. For example, Anna Grear has demonstrated how the unitary subject of law foregrounded within liberalism serves to advance 'an abstract, socially decontextualised, hyper-rational, wilful individual systemically stripped of particularities, complexities and materiality' (2007, p. 522). Costas Douzinas has also critiqued the atomisation of liberal human rights discourse, stating that

human rights, as a special type of recognition, come into existence and can be exercised only in common with others... Rights do not find their limits in others and community, as liberal theory claims. On the contrary, if the function of rights is to give rise to reciprocal recognitions, they presuppose the existence of others and of community. (2000, pp. 286-287)

In this respect, human rights problematically further bounded, as opposed to intersubjective, ideas of the individual which are conceptually one-dimensional and cohere with liberal, capitalist regimes.

This critique of the bounded and atomised individual underpinning liberal human rights has also been linked to critique of the concept of the 'human' which has come to drive the idea of rights in the modern period. Human rights in contemporary liberal discourse are presented as inalienable rights that all possess by virtue of their basic humanity. Not only is the human subject a bounded individual, in being presented as a largely taken-for-granted concept, the 'human' within liberal human rights forecloses how, as Wendy Brown has highlighted, rights do not just attach to a natural human subject "but rather produce and regulate the subjects to whom they are assigned' (2004, p. 459). A related critique has been levelled by Sokhi-Bulley (2012) who characterises rights as tools of governmentality, where individuals govern themselves through rights. Human rights cannot be perceived as possessions of a pre-existing human subject, but are a fundamental part of creating such subjects and restrictive ideas of the 'human'. Many critical engagements with human rights have highlight the gendered, Western and ableist parameters of the liberal idea of humanity which human rights have served to reinforce throughout most of the twentieth century, and have sought to rework such ideas (Bunch 1990; Mutua 1995; Lloyd 2007). The 'human' in liberal human rights discourse has been critiqued, 
therefore, in its foreclosing of relations of power governing which lives can be perceived as human and in encouraging subjects to encounter themselves and others through dominant discourses of 'humanity'.

Indeed, liberal human rights can be problematised more generally as operating to reify existing regimes of power, rendering human rights impotent in staging a more radical challenge for those on the margins. In the modern period human rights have become increasingly tied to state and have, it has been argued, been co-opted by state agendas and their maintenance of power relations beneficial to dominant elites. Zigon (2014), for example, has asserted that human rights are fundamentally limited 'as a language for radically progressive politics'. Zigon (2014) elaborates that, 'every repetition of rights language further solidifies this necessary link between rights and the state-systemic-matrix'. For Zigon, while strategic usage of rights by radical politics may have short term utility,

in the long run the historically accumulated limitations this language carries with it significantly decreases possibilities for imagining, articulating, and ultimately acting in ways to address these issues, abuses, and injustices that go beyond the current configuration of the state-systemic-matrix. (2014)

Following such critique, the intertwining of contemporary human rights discourse and the state has been perceived as restricting human rights to operate within the given order of institutional power. The language of human rights and key human rights concepts such as 'equality' and 'liberty', in this view, retain an interpretation which coheres with current relations of power and offer limited possibilities to be used in a way that facilitates more than a limited shift in such relations.

A further problematic element of liberal human rights in the modern period has been the way in which the politics of human rights often closes off political debate and engagement through an excessive pursuit of consensus. In Douzinas' terms, 'rights belong to the consensual domain of politics' (2007, p. 107). For example, the creation of treaties and key international human rights documents are frequently described in terms of consensus achieved through reasoned dialogue and discussion between states and their conflicting interests, values and cultural perspectives (Cerna 1994, pp. 740-742; Merry 2006, pp. 42-44; Morsink 1999). The legitimacy and authority of the international human rights framework is bolstered by the fact that its treaties, conventions and other declarations have been consensually produced (Donnelly 2013, pp. 57-60). At the local level human rights are also often viewed as facilitating consensual outcomes between competing parties through rational discussion or, indeed, through forced consensus where human rights serve to close down political debate (Ignatieff 2001, p. 300). This focus on consensus in liberal human rights has been critiqued as obscuring key elements such as the messiness and unpredictability of the politics of rights, the ineradicable nature and importance of political disagreement and the performativity of the practice of rights (Zivi 2012, pp. 24-42).

It is such critiques that have led some critical thinkers to abandon the discourse and practice of human rights in radical politics aiming towards radical social transformation. Seminal amongst these has been David Kennedy's advancement of moves away from human rights, asserting, amidst other concerns, that human rights 
occupy the field of emancipatory possibility to the detriment of other, more valuable, emancipatory strategies (2002, p. 108). For Kennedy,

even very broad social movements of emancipation - for women, for minorities of various sorts, for the poor - have their vision blinkered by the promise of recognition in the vocabulary and institutional apparatus of human rights. They will be led away from the economy and toward the state, away from political/social conditions and toward the forms of legal recognition. (2002, p. 110)

However, not all have followed the same approach as Kennedy; many critical engagements with human rights have indeed sought to retain the discourse of rights albeit in a slightly reconceptualised form (Douzinas 2000, 2007; Wall 2012; Zivi 2012). One strand of thinking which has recognised the limitations of liberal human rights but has nevertheless sought to re-engage the discourse of rights in radical politics has been that which draws from radical democratic resources.

The radical democratic tradition can be understood as a diverse collection of thought emerging from the work of Ernesto Laclau and Chantal Mouffe in response to the crisis affecting Western left-wing politics and thinking, especially the Marxist tradition, in the latter half of the twentieth century (Laclau and Mouffe 1998, 2001, pp. vii-xix). Marking a fundamental break from both liberal and socialist interpretations of democracy, radical democratic thought sought to launch a nonessentialist project based upon the openness of the political and the social, founded on articulation as a political practice, challenging the essentialism and foundationalism of Marxism, and dedicated towards widening and deepening the remit of liberal democratic principles such as liberty and equality (Laclau and Mouffe 1998). Laclau and Mouffe's Hegemony and Socialist Strategy employed Gramscian theory, liberal democratic discourse on rights and citizenship, poststructuralism and psychoanalysis to develop a political theory that spoke to the specificity of contemporary political antagonisms and that highlighted the anti-democratic elements within socialism as well as liberalism (Mouffe 2005b, p. 10). The overall contribution of Hegemony and Socialist Strategy contained a theoretical aspect, contributing to the critique and revitalisation of Marxist theory using engagements with Gramsci's concept of hegemony; and an interlinked political aspect, offering the left a project that dismantles the ontological privilege of 'class' and links workers' struggles with other social movements, for example, those against racism, sexism and homophobia, in hegemonic politics (Laclau and Mouffe 1998, 2001, p. xviii). Following the work of Laclau and Mouffe radical democratic thought has developed in a range of directions using a variety of diverse resources (see Connolly 1998, 2005, 2006; Norval 2006, 2007; Rancière 2004a, 2006). ${ }^{1}$

Amongst other attempts to address the shortcomings of liberal human rights, those using radical democratic thinking stand out as particularly useful in offering a variety of inter-related tools and resources to rework human rights beyond their liberal limitations, but also the possibility to link such re-engagements with human rights to a radical critique of power within a wider project for radical democracy.

\footnotetext{
${ }^{1}$ For further exploration of contemporary radical democratic thought see Thomassen (2010).
} 
Viewing human rights through the lens of radical democratic theory, therefore, not only offers resources for human rights to be radically reimagined, but also allows human rights, so reimagined, to become part of broader attempts to rework liberal democracy and its restrictive relations of power more generally. While by no means a fully developed body of thought, attempts can be detected in critical literature to reconceptualise and reclaim rights through the use of radical democratic theory. Two of the most substantiated accounts can be found in the work of Samuel Chambers and Jacques Rancière. Chambers' work seeks to reinvigorate the discourse of rights by displacing it from the terms of liberalism and moving it towards more radical potential using Laclau's writings on universality in particular (for example, Laclau 1996). The salience of Laclau's work for Chambers lies in the possibility to 'interpret rights as empty signifiers that mediate the gap between universal and particular' (2004, p. 197). Rights in this view signify the absent fullness of the universal about which Laclau speaks, but only the particular political demands - the hegemonic articulation - of a group or groups can fill the empty universal with a temporary, particular content (Chambers 2004, p. 197). Chambers states, therefore,

what I am suggesting here is not simply that Laclau's political reinterpretation of the relation between universal and particular can give us a better way of understanding the role of rights in contemporary politics... but also that the viability of hegemonic politics today depends upon the discourse of rights. (2004, p. 197)

Similarly, Rancière has utilised radical democratic resources to rethink human rights and the democratic possibilities they offer. Critiquing what he sees as Hannah Arendt's depoliticisation of rights via her identification of the human with mere life (zö̈) and the citizen with the good life (bios politikos) (Arendt 1951), Rancière articulates the 'human' of human rights as a contested and litigious name which is a condition of possibility for politics (2004b, pp. 299-300). In contrast to the liberal tradition which he characterises as a police order, Rancière conceives of the political in terms of impurity and the staging of a dissensus in which those who are deemed to lack the 'human' of human rights make themselves heard, invoking the litigious name of the 'human' to assert a fundamental equality, to politicise the division between those qualified for participation in politics and those deemed not. Rancière understands the politics of human rights in a radical democratic vein as a creative democratic politics of contention and disruption, challenging social exclusions in the name of the open-ended principle of equality which acquires its particular contours only through dissensual contestation (Ingram 2008, p. 413).

These works are significant in gesturing towards a future for human rights beyond liberalism and for human rights to link into wider attempts to radicalise democracy. My discussion below seeks to pick up the conversation between radical democratic theory and human rights and articulate more of how drawing from radical democratic recourses holds potential to address the shortcomings of liberal human rights. I assert that further possibilities exist to productively rethink human rights in radical democratic terms by returning to resources offered in the work of Laclau and Mouffe. In doing so I aim to build upon the accounts of Chambers and 
Rancière; following their introduction to the potential to reimagine human rights using radical democratic theory, much remains to be considered of the specific resources within radical democratic thought which allow us to do so. Laclau and Mouffe's work demonstrates points at which the work of Chambers and Rancière may be departed from, or the ideas they advance productively considered in a slightly different way. Returning to Laclau and Mouffe also allows us to explore more of a significant question which remains after Chambers and Rancière; how human rights, radically re-engaged, may figure within a wider project for radical and plural democracy.

\section{Radical Democratic Resources for Re-engaging Human Rights}

In this section I foreground three key elements of Laclau and Mouffe's work which can be highlighted as useful in re-engaging liberal human rights: critical engagement with power and liberalism; the utility of antagonism; and the idea of futurity. While these elements interlink with discussion initiated by Chambers and Rancière, returning to the work of Laclau and Mouffe allows us to expand consideration of them: how they can help reimagine human rights in productive ways, and how human rights politics can be thought to become part of a wider project for radical democracy as initially imagined by Laclau and Mouffe. In drawing from Laclau and Mouffe in such a way discussion is also taking their own work in a new direction, bringing it into conversation with human rights and identifying human rights as potentially a key site for contemporary radical democratic activity in a way not specifically explored in Hegemony and Socialist Strategy. ${ }^{2}$

The first element I wish to engage in Laclau and Mouffe's work is perhaps the central kernel of radical democratic thought itself; a critical relation to power and liberalism. This has significant implications for how we can view liberal resources and ideas such as human rights. At a fundamental level the radical democratic project can be considered 'radical' because it involves issuing a profound challenge to existing relations of power and liberalism's reifying of such relations. Laclau and Mouffe's concern begins with a critical approach to power, including, but not limited to, economic power within existing liberal democracy. Their project for radical democracy aims to achieve a transformation of social relations through democratic politics, widening and deepening the remit of liberal democratic principles such as liberty and equality towards radical pluralism (Laclau and Mouffe 1998, 2001, p. 160). ${ }^{3}$ Laclau and Mouffe's radical democracy involves both a commitment to and a radicalisation of the key tenets of liberalism and liberal democracy. They outline that

\footnotetext{
${ }^{2}$ While Laclau and Mouffe do employ liberal democratic discourse on rights in their rethinking of the political and the social, they do not directly engage in a project to reimagine rights in radical democratic terms.

${ }^{3}$ For more on this meaning of pluralism see Mouffe (2005a, p. 7).
} 
the problem, with 'actually existing' liberal democracies is not with their constitutive values crystallized [sic] in the principles of liberty and equality for all, but with the system of power which redefines and limits the operation of those values. (Laclau and Mouffe 2001, p. Xv)

The radicalisation of democracy that they advance consists of 'a profound transformation of the existing relations of power' within the context of liberal democracy (Laclau and Mouffe 2001, p. xv). This denotes moves from liberal pluralism towards a deeper, more radical pluralism which extends beyond mere liberal assimilation and inclusion; moves from the possessive individualism of the liberal subject towards a view of the subject which is more relational; and challenges to liberal regimes of power through hegemonic politics.

This fundamental element of Laclau and Mouffe's work holds foundational potential for re-engaging with liberal human rights. As outlined above, a key reason for the critique of human rights in their liberal form is that they reinforce existing restrictive relations of power as opposed to facilitating challenge of them. Presently the challenge which human rights pose to existing regimes of power is considerably limited given the commitments they demonstrate to individualism, capitalism and state-led agendas. However, when we view liberal human rights through Laclau and Mouffe's thought we can see that human rights need not be discarded straight away because of their liberal commitments and current attachment to restrictive power regimes. As Illan Wall states, echoing radical democratic sentiment, 'to simply cede human rights to the liberal tradition is to fail to understand the significance of the democratic tradition in human rights' $(2012$, p. 3). Rather, human rights may be viewed as one liberal discourse which stands to be reworked, which can be reengaged in the context of a critical relation to power in order to make the values it espouses more concrete and thereby advance a more meaningful realisation of the key values of liberal democracy.

This is something that is not possible to assert from all writers in the radical democratic vein. Rancière, for example is highly sceptical of attempts to maintain liberalism or its resources in any form (see Chambers 2013, pp. 10-14). From Laclau and Mouffe's perspective, however, the principles such as equality, dignity and liberty which liberal human rights are built upon are not problematic in and of themselves. Rather, it is the way in which these principles are interpreted and employed within liberalism and its restrictive regimes of power which is objectionable. Bringing human rights into conversation with Laclau and Mouffe's thought allows us to re-evaluate human rights as a part of modern liberal democracy currently hindering more radical possibilities but a liberal discourse which may be productively reworked if we can expand the values that rights represent in a way that facilitates radical pluralism. Thus, returning to the central kernel of Laclau and Mouffe's thought allows us from the outset to make an argument against abandoning human rights as too engrained within liberalism, and to begin to consider ways in which human rights may be a resource capable of reworking to challenge, as opposed to reify, already existing relations of power.

A second element within the work of Laclau and Mouffe which can be advanced as holding productive possibilities to re-engage human rights relates to the ideas of 
conflict and antagonism and their role within politics. Another key problem with liberal human rights outlined above is their attachment to discourses of consensus, often foreclosing the productive possibilities that sustained conflict offers democratic human rights politics. Resources can be found in radical democratic thinking to re-engage human rights politics beyond consensus to allow more radical possibilities to emerge through a return to the value of conflict in democratic politics. Laclau and Mouffe regard as dangerous the idea that consensus is a desirable political aim that will eradicate all power struggles (2001, pp. xiv-xv). One of the most significant and defining tenets of their project for radical democracy is a commitment to the democratic utility, and indeed ineradicable nature, of antagonism. This is a value which necessarily emerges from experiences of radical political pluralism advanced in contrast to liberalism's mere inclusion or assimilation and is central to the hegemonic politics they advance. Laclau and Mouffe's antagonism challenges objectivist accounts of social conflict which view antagonism in the sense of agents with fully constituted identities and interests clashing with one another in a way which requires resolution. On the contrary, they assert that antagonism can never be resolved without the elimination of the political itself. The relationship between antagonism and democracy in this view is not one of equivalence or opposition, rather antagonism poses the question of the demos itself, and the project of radical democracy embraces and incites an infinite series of contingent contestations as part of hegemonic politics.

The idea of conflict or contest is a radical democratic resource central to Rancière's re-engagement with rights. Rancière's approach is powerful in highlighting human rights as a possible vehicle to facilitate the political in staging a disruption of rational, consensus-based politics and their limited potential for radical social transformation. In Rancière's terms human rights can facilitate politics proper in the sense of staging a "division put in the "common sense": a dispute about what is given, about the frame within which we see something as given' (2004b, p. 304). In addition to staging radical moments of conflictual disruption where those previously outside the remit of the 'human' speak (as gestured towards in Rancière's account), the value of conflict and antagonism in radical democratic thinking can be used productively, returning to Laclau and Mouffe, to conceptualise human rights in terms of antagonistic hegemony more generally; one space for hegemonic politics which sustains antagonism in democratic politics and feeds into a wider project for radical democracy. In order to move human rights beyond liberalism the politics of human rights may be viewed as fundamentally hegemonic, as about constantly contesting what their key values mean and the relation between rights and dominant regimes of power. This allows us to come to view human rights as inherently about contest: a conflictual exercise in which the content and remit of rights is constantly made and remade through hegemonic politics within contexts of power. Linking into Mouffe's own work, as opposed to a destructive, unproductive contest, this hegemonic contest can be perceived as taking the form of agonism where those engaging in such politics do so as adversaries (see Mouffe 2005a, p. 20). While all may be committed to the concept of human rights and the broad values they espouse, indefinite contest may, and must, take place over the particular significations of rights in specific contexts at 
specific times. Thus, rather than viewing the politics of human rights as about seeking consensual outcomes, the vision of hegemonic politics that Laclau and Mouffe advance can aid re-imagination of a human rights politics which is fundamentally dissonant, reflecting the ineradicable nature of social conflict more generally, encouraging hegemonic contest as a means of opening discussion on what the values of liberal human rights mean, and what they could potentially be conceived to mean anew.

The final resource which Laclau and Mouffe's work can be perceived as offering for a productive addressing of the limitations of liberal human rights is potential for disrupting how the temporality of human rights and their politics is perceived. Laclau and Mouffe's thought may be drawn upon to direct towards a futural sense of human rights which reflects the futural character of democracy more generally. Within their work radical democratic politics consists of a striving towards a complete, fully inclusive and ideal democracy which remains 'to come', a selfrefuting idea which 'should be conceived as a good that only exists as good so long as it cannot be reached' (Mouffe 2005b, p. 8). The horizon for radical democracy in this view is the (impossible) realisation of democracy itself. Rather than a flaw, however, it is the promise of such realisation which sustains democracy and democratic politics. Here Laclau and Mouffe are indebted to Jacques Derrida and indeed acknowledge the foundational influence of Derrida's work on their concept of radical democracy (2001, pp. xi-xii). Radical democracy is 'to come' in Derrida's sense that,

democracy remains to come; this is its essence in so far as it remains: not only will it remain indefinitely perfectible, hence always insufficient and future, but, belonging to the time of the promise, it will always remain, in each of its future times, to come: even when there is democracy, it never exists, it is never present, it remains the theme of the non-presentable concept. (Derrida 2005, p. 306)

This futural conception of democracy employed in context of Laclau and Mouffe's work holds two possibilities for human rights. Firstly, as a democratic practice aiming towards realisation of key democratic ideals such as liberty and equality, human rights can be characterised as a site for working towards a radical and plural democracy to come. In addition, secondly, human rights can be characterised as equally futural as democracy itself; an unfinished project whose complete achievement remains just out of grasp and which is spurred on by that which it excludes-the alterity always haunting human rights. The concept of futurity gestured towards here fundamentally differs from liberal perspectives. Liberalism may agree that human rights remain a futural concept to be constantly strived towards, but the perspective on futurity that we can gather from Laclau and Mouffe is more radical in that it involves maintaining a critical relation to power, to that which is excluded from any hegemonic idea or discourse, and using this to drive a futural politics.

Disruption of the temporality of human rights is found in Chambers' radical democratic revision of human rights. Considering the work of Ernesto Laclau and Judith Butler on universality, Chambers engages with the themes of formalism, 
futurity and hauntology in Laclau and Butler's discussions which he reads as highlighting the untimeliness of democracy to come (2003, p. 163). For Chambers, we can think of rights in radical democratic terms as 'ghostly rights' which 'suggests the need to theorize [sic] a concept of rights through the logic of the ghost, while it also implies a reconsideration of rights as themselves spectral' (2003, p. 163). However, while a useful formulation, this may move from the value of the futural too soon without fully engaging with the productive possibilities it offers for re-engaging liberal human rights. Conceptualising human rights as inevitably futural involves conceiving the values human rights promote as values that can never be fully realised or achieved, in fact such a result would cause rights to lose their raison d'être. This conception should push us towards a never-ending democratic striving for these values and the conception of our lives together that they promote within wider democratic contexts. The essence of human rights politics accordingly becomes not the positivisation of rights, nor work to secure measurable human rights compliance, but the promise of a new, better and radically plural world that rights represent which must remain self-refuting. This futural element directs attention towards the possibilities which human rights offer; the promise of complete realisation of liberal democracy's key ideals and of alternative ways of living and being together which address the shortcomings of current liberal regimes. It is this futural promise which allows human rights and their politics to be used in working towards radical social transformation. In this way the politics of human rights viewed in a futural way may fit with a wider politics of democracy to come; human rights emerge as a micro-location for democratic activity towards completely achieved radical and plural socio-political relations which always remain just out of grasp and so may form one site for struggle towards a radical and plural democracy which always remains to come.

Thus, from the above, the work of Laclau and Mouffe can be returned to in order to further foreground the value of radical democratic theorising for addressing the shortcomings of human rights in their current liberal form, and can be used to add to, even at times move in a slightly different direction from, the discussion of rights in radical democratic terms initiated by Chambers and Rancière. We can see how Laclau and Mouffe's work offers productive theoretical resources to radically reengage human rights in a new way beyond liberalism-re-engagements with power and liberalism as well as the concepts of antagonism and futurity-and, thinking Laclau and Mouffe beyond themselves, human rights may even become a site for activity striving towards radical and plural democracy. However, in articulating more of the uses of radical democratic resources to re-engage human rights one notable omission in work to date also requires addressing: the lack of discussion on the way in which human rights can be practically approached in radical democratic terms. Little tangible detail has been outlined as to what a radical democratic practice of human rights would look like. How can the human rights politics be thought and consciously approached in radical democratic terms?

This question is crucial for activists, but also for scholars or commentators who remain sceptical that human rights can be productively re-engaged after their critique. Those unconvinced about the utility of or the way in which human rights can be radically reimagined require theoretical re-engagements which hold potential 
to redress the shortcomings of liberal human rights, but also an approach which can demonstrate a persuasive way to radically practice human rights. I assert that the radical democratic resources outlined above can offer both, and the latter can be teased out through development of Judith Butler's concept of cultural translation which may offer a useful bridge between Laclau and Mouffe's radical democratic theorising and the practice of human rights. In analysis below Butler's concept of cultural translation is foregrounded as underpinned by fundamentally radical democratic elements and can be brought into conversation with rights to offer a lens through which universal human rights concepts may be re-read and a framework to engage in human rights politics in a radical democratic manner. Indeed, these are tools that resonate with already existing work seeking to utilise human rights to challenge restrictive regimes of power, and so the bridge of cultural translation, grounded in both radical democratic theorising and holding potential to build upon already existing activist work, holds possibilities to persuade those sceptical about the radical potential of human rights and furthers the utility of radical democratic thought after the critique of rights.

\section{Thinking a Radical Democratic Practice of Human Rights}

\section{Cultural Translation and Its Radical Democratic Foundations}

Cultural translation emerges as a model in Butler's work interlinked with her thoughts on universality (1996, 2000, 2004, pp. 25-39). For Butler, any universal is never fully complete due to its inevitable formation within particular cultural locations (see Butler 1996). Competing accounts of the universal, also articulated within culture, exist at any one time and come into translational dialogue with one another in the model of cultural translation (Butler et al. 2000, pp. 37-38, 162-164). Cultural translation can be thought of as a practice whereby the unfixity of any universal concept is foregrounded and constantly reworked through translational dialogue between its current form and that which it excludes or forecloses, represented in the competing universal. The result of this translational dialogue is the subversion of the existing universal by revealing what is excluded from it, and its reworking on the basis of its own alterity (Butler et al. 2000, pp. 11-43).

However, when competing universals come into translational dialogue the current universal will not merely integrate or include the demands made upon it to create a 'truer' universal, but both must change in order to apprehend the other (Butler 1996, p. 48). In this view, universality is a process which takes place within hegemonic and contingent cultural negotiations (Butler et al. 2000, pp. 3-14). Any universal can never be all-encompassing or complete, it 'belongs to an open-ended hegemonic struggle' (Butler et al. 2000, p. 38). The result of translational dialogue between competing universals is the creation of a new universal which speaks to the limits of the former but which can never be fully complete, inclusive or settled, and so becomes the new, dominant universal which is open to challenge from that which it excludes. This translational work is not a straightforward or predictable process; it may or may not succeed in enhancing the claims of those at the limits of current 
hegemonic discourses. However, feeding into Butler's wider ontological project, cultural translation appears as a useful model to challenge dominant paradigms based upon the claims of those on the margins.

Why is cultural translation being advanced here as capable of development to provide a useful link between the radical democratic theory and practice of human rights? The answer is that a commitment to the key elements of Laclau and Mouffe's radical democratic thought explored above can be perceived underpinning this model. While by no means a radical democratic theorist per se, radical democratic elements can be found in Butler's work (see Lloyd 2008; Schippers 2008; MacKenzie 2008). In particular, Moya Lloyd highlights cultural translation as central to Butler's radical democratic commitments, stating that 'reading her at her most radical, democratic transformation for Butler can and will occur only when... subjects "exist [...] in the mode of translation, constant translation", (2008, pp. 37-38 citing Butler 2004, p. 228). Moreover, Butler herself elaborates that cultural translation is directed towards the assertion of 'new normative schemas that would imply a rigorous critique of misogyny, homophobia, and racism in an effort to articulate a social and political world characterized [sic] by interdependency, equality, and even radical democracy' (Butler et al. 2012, p. 2 emphasis added).

Fitting with Laclau and Mouffe's work, the practice of cultural translation is a means of challenging hegemonic (liberal) power regimes towards more inclusive and less restrictive possibilities and aims to do so through the facilitation of sustained contestatory dialogue taking place in the form of translation. The model emerges from a perception of universality as a site of contest and is a way of moving currently static, liberal conceptions of the universal toward endless conflictual reworkings (Butler et al. 2000, p. 37). The contest that takes place in cultural translation is a fundamentally hegemonic contest. As Angela McRobbie states, cultural translation can be conceived of as 'the space for renewed hegemonic politics better able to "shatter the confidence of dominance", (2004, p. 507 citing Butler et al. 2000, p. 179). Cultural translation also demonstrates a fundamental commitment to futurity, opening democratic engagement with the universal as a 'not yet' in a context where, as Butler recognises, democracy too must be unknowing about its future (Butler et al. 2000, p. 41). The new discourse emerging from contestatory translational dialogue evades liberal notions of final resolution and assimilation, the ongoing work of cultural translation being to strive towards a radical pluralism which rejects absolute synthesis and retains the critical force of alterity. Butler stresses universality as necessarily open-ended and views the task of democratic politics as being to maintain the universal as a site of permanent crisis, never to be settled (Butler et al. 2000b, p. 747).

Cultural translation thus appears as a means of encouraging engagement with universal concepts in a way that is fitting with a radical democratic commitment to antagonistic, and futural, hegemonic politics challenging dominant power regimes in a radical democratic sense. Engaging in practices of cultural translation involves undertaking contestatory political activity which shatters ideas of fixity without certainty about what will come, but doing so in order to work towards the promise of an ideal form of the political and social which is always self-refuting. This unrealisability should not deter political engagement, but appears as the very 
practice of radical politics itself (Butler et al. 2000, p. 268). Given these radical democratic underpinnings, I assert that cultural translation stands to be developed to provide tools for a radical democratic practice of human rights.

\section{Tools of Cultural Translation for a Radical Democratic Practice of Human Rights}

It is possible to bring the model of cultural translation into productive dialogue with human rights in order to envisage two tools which can help bridge the gap between the radical democratic theory and practice of human rights. Expanding Butler, what I see cultural translation as holding potential to provide is a lens through which human rights may be re-read anew and a framework which may be employed to direct engagement in human rights politics in a radical democratic way. Both these tools will be considered in turn and the way in which they resonate with already existing human rights activism. I assert that these resonances may be built upon in order to encourage contemporary activists to consciously think of their work in terms of cultural translation and link it into a wider radical democratic project.

The first element which cultural translation can be thought to provide for a radical democratic practice of human rights is a lens through which rights may be re-read. This can be seen as a necessary first step in a radical practice of human rights; actually perceiving rights as capable of being worked in a new way beyond liberalism which facilitates radical pluralism. The lens that cultural translation offers encourages current liberal human rights concepts to be viewed as not static or fixed, but as currently hegemonic ideas made within cultural contexts which stand to be challenged by alternative conceptions of themselves articulated by, amongst others, radical political groups. This lens reveals the inherent unfixity of universal human rights concepts and demonstrates that the shortcomings of current articulations are not a reason to call for a wholesale rejection of human rights. On the contrary, it allows such shortcomings to come into view as the starting point for human rights concepts to be remade through conflictual, counter-hegemonic democratic engagement on what rights can be used to do, say or achieve. This approach differs from the liberal view of rights in that while liberalism may accept that human rights are relatively unfixed and open to continual development, the lens of cultural translation locates such unfixity within the context of power. Current human rights concepts are necessarily tied to restrictive regimes of power within liberalism, but when we view such concepts through the radical democratic lens of cultural translation we see that possibilities exist 'for expanding the democratic possibilities for the key terms of liberalism, rendering them more inclusive, more dynamic and more concrete' (Butler et al. 2000, p. 13). The lens of cultural translation allows human rights concepts to be read as always a product of particular cultural and politico-historic contexts, always necessarily limited by them, and to begin to understand continual counter-hegemonic challenges to their current articulation within scenes of power as the work of human rights politics.

One location where the lens of cultural translation may be employed to initiate a radical practice of human rights is in relation to discourse on the 'human'. As highlighted above, the site of the 'human' has been a key point for critique of liberal 
human rights and their relation to restrictive discourses of power; the human of human rights is not a 'natural' concept, as liberal discourse would have us believe, but is a fundamentally political creation. Using the lens of cultural translation, the 'human' can be re-read as a hegemonic concept, created within a particular cultural location, so reflecting related regimes of socio-political power, but one which is open to reworking towards radical pluralism based on its constitutive alterity. This is something that Butler recognises has taken place in lesbian, gay, bisexual and transgender (LGBT) rights human rights activism. Butler highlights the re-reading of and translational contestation over the concept of the 'human' which LGBT activism has involved (1996, p. 46) and endorses use of cultural translation in this way, stating 'how might we continue to insist upon more expansive reformulations of universality, if we commit ourselves to honoring [sic] only the provisional and parochial versions of universality currently encoded in international law?' (1996, p. 47). LGBT activists can be viewed as engaging the lens which cultural translation offers to apprehend current discourse on the 'human' as limited but open to counterhegemonic articulation through democratic politics to rework this concept in a way which is more radically plural. Claiming rights as human even though excluded from the current articulation of this concept begins with re-reading human rights and their current limits in contexts of power, and using this lens to start to think through their use to widen and deepen the remit of the liberal democratic principles which human rights represent.

The lens of cultural translation can be viewed as relevant to a range of groups interested in the practice of human rights in a way that challenges current restrictive regimes of power. Another example is migrant rights. While human rights to equality, the right to work and right to be free from torture and inhumane and degrading treatment, for example, are provisions relevant to addressing situations many migrant workers experience, these concepts have been traditionally interpreted in a way that coheres with the agendas of Western states, state sovereignty and liberal economy, which benefit from the suppression of migrant workers' rights. In the late twentieth century migrants and their advocates began to read these provisions as inadequate to respond to the particular experience of migrant workers. Such activity led to the enactment of the International Convention for the Protection of All Migrant Workers and Their Families in 1990. Migrant rights activists can be considered as employing the lens of cultural translation in this work; re-reading human rights as currently limited and reifying hegemonic regimes of power, but as unfixed and capable of reworking towards to facilitate more radical pluralism. In this way the 'counter-hegemonic discourse of migrants' rights provides the language to the excluded groups of migrants... to claim rights from which these migrants are excluded' (Basok 2009, p. 190).

Naturally, this lens that encourages re-readings of human rights must be followed up using the second tool which cultural translation can be thought as offering; a related framework for politics. This framework can be perceived as the way in which the realisations facilitated by the lens of cultural translation can be acted upon to allow for the practical reworking of human rights. In this framework the object of challenge for radical politics is a particular universal rights concept or idea viewed as inadequate in its current form. Challenge to rework this concept in a way which 
moves it beyond its current liberal articulation can be carried out by counterhegemonic assertions of alternative, competing conceptions of this universal made by those that the current concept presently restricts or excludes. These competing universal concepts - the currently dominant and the challenging-can be consciously brought into conflictual dialogue and translation be encouraged between them in spaces such as local politics, law reform, domestic and international courts, UN fora and a plethora of other locations where human rights politics take place. The desired result will be the emergence of slightly modified or altered conceptions of what rights are, what they can achieve and/or in relation to whom. This conflictual process should be seen as having an inherently futural character; the newly modified universal, while slightly more expansive, is still limited and can be no more fixed than that which preceded it.

Use of this framework can be detected in the examples of LGBT and migrant rights activism above which, following a re-reading of dominant liberal human rights provision, articulated competing universals reworking such provision. Another example of where activists engaged in an approach resonating with this framework is women's rights activism. The 1990s' feminist campaign for 'Women's Rights as Human Rights' began with a re-reading of current human rights provision as structured by masculinist regimes of power (Bunch 1990; Charlesworth 1995; Chinkin et al. 1991). After coming to view these current human rights concepts as limited, constituted by alterity within the context of gendered power, and unfixed, open to counter-hegemonic engagement, women's rights campaigners engaged in the activity of asserting competing universals. Activism at international and local levels highlighted the inadequacy of current universal human rights provision to encompass issues such as domestic and sexual violence and reproductive health, asserting competing conceptions of rights and their subject which exposed the currently hegemonic discourse as exclusionary and open to a more radical pluralism. In a range of global and local locations women's rights activists engaged these competing universals in conflictual translational dialogue with dominant articulations of human rights, the result being the emergence of a new, slightly modified universal discourse incorporating gendered issues into the international human rights corpus (Fraser 1999; Peters and Wolper 1995; Cook 1994). However, the analysis that the cultural translation framework offers does not end there. In recent years feminist analysis has voiced frustrations with the discourse resulting from the translational work of the 1990s. Critique has highlighted the liberalism and heteronormative assumptions about 'sex' and 'gender' which underpins much provision secured following the 1990s' campaign (McNeilly 2014; Cossman 2002; Otto 2013). Here the framework of cultural translation may foreground the futural nature of a radical practice of human rights. If universal human rights are ineradicably futural, never finally fixed or settled, and contestation is at the heart of human rights politics, activists must rework human rights through ongoing assertion of competing universals which challenge the dominant, even have a duty to do so within a wider democratic struggle for fully complete democracy, meaning that the achievements of the 1990s should be viewed as the current universal open to challenge as the inadequate discourse which preceded it. 
Cultural translation, therefore, can provide a useful lens to begin to re-read human rights within a critical relation to power and an inter-related framework to actually approach the practice of human rights as the staging of counter-hegemonic competing universals to rework the limits of current human rights concepts through conflictual translational dialogue which sustains the futurity of human rights politics. For Butler, the ongoing and futural making and remaking of universal discourse via the practice of cultural translation can be perceived as central to any healthy and democratic human rights politics (2004, p. 36); in particular, we might add, a radical democratic human rights politics. From engagements above with LGBT, migrant workers' and women's human rights activism we can see that those interested in advancing radical politics utilising the discourse and practice of human rights are indeed already engaging in activity which reflects key elements of the approach cultural translation envisages. ${ }^{4}$ Thus, in advancing cultural translation as towards a radical democratic practice of human rights what appears to be required is to encourage activists to continue to approach human rights in such a way but to begin to consciously frame their work in terms of the lens and the framework of cultural translation, aware of the radical democratic leanings of such activity. Activists can be encouraged to view their activity to rework human rights as work towards radical pluralism, furthering the reach of key ideas such as liberty and equality, part of a wider project for radical and plural democracy, and thus link their work and the objectives it pursues into a broader reworking of liberal democracy that Laclau and Mouffe envisage. From this, human rights activism may emerge as one part of sustaining the project for radical democracy, one location where liberal democracy and its principles can be reworked and activity undertaken towards democracy to come. It is in this way that cultural translation can help envisage a radical democratic practice of human rights that resonates with already existing activist work, offering resources to further such work, as well as possibilities to expand it in new directions within the remit of a wider project for radical and plural democracy.

In emerging as a model grounded in theoretical resources seeking to address the current shortcomings of human rights within liberalism and one which has clear resonances with already existing activism, cultural translation appears powerful to address those scholars and commentators who may remain sceptical as to work to re-engage human rights in radical politics. Those who advance that the limitations of human rights within liberalism are too great to surpass may remain unconvinced by the use of theoretical resources in re-engaging human rights, given the abstract nature of such an activity. However, in linking radical democratic theory with already existing attempts to re-engage human rights and offering resources to build upon such activity in a tangible way, cultural translation moves the project to radically reimagine human rights in, arguably, a more persuasive direction. Indeed, cultural translation may be thought as offering a role for scholars and commentators on the left, encouraging them too to become engaged in the work of asserting competing universal ideas about what human rights are capable of doing, saying and meaning which interlinks with wider practical activity to rework human rights in

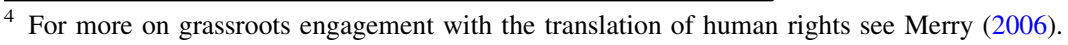


hegemonic politics more broadly. Conflictual translational work is not limited to the streets, courtrooms or UN fora but may be thought of as taking place in a range of locations that include the academy. Thus, whether as activists or as scholars, cultural translation helps envisage possibilities for engaging in a radical democratic practice of human rights and provides tools to do so, naturally linking the work of Laclau and Mouffe and its usefulness in re-imagining human rights with everyday engagement with rights.

\section{Conclusion}

The critique of human rights within critical legal thought has been powerful, revealing crucial ways in which liberal human rights are necessarily restrictive in advancing the aims of radical politics. Equally powerful, however, have been attempts to reimagine and re-engage human rights after this critique within radical literature. Radical democratic thought emerges as one resource drawn upon within such attempts and, given the variety of tools it offers and the way in which these tools can be linked into a wider critical project for plural and radical democracy, one particularly useful resource. In this article I have sought to demonstrate the way in which the discussion of human rights in radical democratic terms can be expanded by returning to the work of Laclau and Mouffe to characterise human rights as one liberal concept which may be re-engaged to challenge instead of reify restrictive regimes of power through characterising human rights politics in terms of antagonistic hegemonic engagement and human rights themselves as futural concepts with a potential role to play within a wider practice for radical and plural democracy. Moreover, via Butler's concept of cultural translation and its radical democratic underpinnings, discussion has demonstrated how radical democratic thought may also offer possibilities to envisage a racial practice of human rights which resonates with already existing activism, also providing tools to further and expand such activity and render the practice of human rights a micro-practice of radical democracy.

It should be noted, however, that the idea of a radical democratic theory and practice of human rights is not asserted here as the 'solution' to the problem of what comes after the critique of rights. Such a straightforward solution cannot be found, certainly not in a singular sense. A radical democratic theory and practice of human rights must be one of many attempts to reclaim the radical in rights. It offers one way to think through radical re-engagements with rights in a useful and accessible way, particularly in conversation with the lens and framework of cultural translation. Perhaps the pursuit of consensus on how to approach rights after their critique is equally as undesirable as the pursuit of consensus in the politics of human rights itself. Therefore, in the spirit of radical democracy, as critical legal scholars and activists we must continue to engage in contestatory thinking towards plausible, albeit never final or all-encompassing, answers to the question of what comes after the critique of rights less we close down the potential and unexpected ways in which rights may be used to speak back to the power that shapes us. 
Open Access This article is distributed under the terms of the Creative Commons Attribution 4.0 International License (http://creativecommons.org/licenses/by/4.0/), which permits unrestricted use, distribution, and reproduction in any medium, provided you give appropriate credit to the original author(s) and the source, provide a link to the Creative Commons license, and indicate if changes were made.

\section{References}

Arendt, Hannah. 1951. The origins of totalitarianism. New York: Harcourt Brace.

Basok, Tanya. 2009. Counter-hegemonic human rights discourses and migrant rights activism in the US and Canada. International Journal of Comparative Sociology 50(2): 183-205.

Brown, Wendy. 2004. "The most we can hope for...": Human rights and the politics of fatalism. The South Atlantic Quarterly 103(2-3): 451-463.

Bunch, Charlotte. 1990. Women's rights as human rights: Towards a re-vision of human rights. Human Rights Quarterly 12(4): 486-512.

Butler, Judith. 1996. Universality in culture. In For love of country? A new democracy forum on the limits of patriotism, Martha Nussbaum with respondents, ed. Joshua Cohen, 45-52. Boston: Beacon.

Butler, Judith. 2004. Undoing gender. New York: Routledge.

Butler, Judith, Ernesto Laclau, and Slavoj Žižek. 2000a. Contingency, hegemony, universality: Contemporary dialogues on the left. London: Verso.

Butler, Judith, Gary Olson, and Lynn Worsham. 2000b. Changing the subject: Judith Butler's politics of radical resignification. JAC: A Journal of Compositional Theory 20(4): 727-765.

Butler, Judith, Claire Pagès and Mathieu Trachman. 2012. Analytics of power: An interview with Judith Butler. booksandideas.net. Accessed May 7, 2015.

Cerna, Christina. 1994. Universality of human rights and cultural diversity: Implementation of human rights in different socio-cultural contexts. Human Rights Quarterly 16(4): 740-752.

Chambers, Samuel. 2003. Ghostly rights. Cultural Critique 54: 148-177.

Chambers, Samuel. 2004. Giving up (on) rights? The future of rights and the project of radical democracy. American Journal of Political Science 48(2): 185-200.

Chambers, Samuel. 2013. The lessons of Rancière. Oxford: Oxford University Press.

Charlesworth, Hilary. 1995. Human rights as men's rights. In Women's human rights: International feminist perspectives, ed. Julie Peters, and Andrea Wolper, 103-113. New York: Routledge.

Chinkin, Christine, Hilary Charlesworth, and Shelley Wright. 1991. Feminist approaches to international law. American Journal of International Law 85(4): 613-645.

Connolly, William. 1998. Rethinking the ethos of pluralization. Philosophy and Social Criticism 24(1): 93-102.

Connolly, William. 2005. Pluralism. Durham, NC: Duke University Press.

Connolly, William. 2006. Immanence, abundance, democracy? In Radical democracy: Politics between abundance and lack, ed. Lars Tønder, and Lasse Thomassen, 239-255. Manchester: Manchester University Press.

Cook, Rebecca (ed.). 1994. Human rights of women: National and international perspectives. Philadelphia: University of Pennsylvania Press.

Cossman, Brenda. 2002. Gender performance, sexual subjects and international law. Canadian Journal of Law and Jurisprudence 15(2): 281-296.

Derrida, Jacques. 2005. The politics of friendship, trans. George Collins. London: Verso.

Donnelly, Jack. 2013. Universal human rights in theory and practice, 3rd ed. Ithaca: Cornell University Press.

Douzinas, Costas. 2000. The end of human rights: Critical legal thought at the turn of the century. London: Hart.

Douzinas, Costas. 2007. Human rights and empire: The political philosophy of cosmopolitanism. Abingdon: Routledge-Cavendish.

Fraser, Arvonne. 1999. Becoming human: The origins and development of women's human rights. Human Rights Quarterly 21(4): 853-906.

Grear, Anna. 2007. Challenging corporate 'humanity': Legal disembodiment, embodiment and human rights. Human Rights Law Review 7(3): 511-543.

Ignatieff, Michael. 2001. Human rights as politics and idolatry. Princeton: Princeton University Press. 
Ingram, James. 2008. What is a 'right to have rights'? Three images of the politics of human rights. American Political Science Review 102(4): 401-416.

Kennedy, David. 2002. The international human rights movement: Part of the problem? Harvard Human Rights Journal 15: 101-126.

Laclau, Ernesto. 1996. Emancipation(s). London: Verso.

Laclau, Ernesto, and Chantal Mouffe. 2001. Hegemony and socialist strategy: Towards a radical democratic politics, 2nd ed. London: Verso.

Laclau, Ernesto and Chantal Mouffe. 1998. Hegemony and socialism: An Interview with Chantal Mouffe and Ernesto Laclau. Palinurus. http://anselmocarranco.tripod.com/id68.html. Accessed May 7, 2015.

Lloyd, Moya. 2007. (Women's) human rights: Paradoxes and possibilities. Review of International Studies 33(1): 91-103.

Lloyd, Moya. 2008. Performing radical democracy. In The politics of radical democracy, ed. Adrian Little, and Moya Lloyd, 33-51. Edinburgh: Edinburgh University Press.

MacKenzie, Julie. 2008. Judith Butler, gender, radical democracy: What's lacking? Transformations 16: http://www.transformationsjournal.org/issues/16/article_04.shtml. Accessed May 7, 2015.

MacPherson, Crawford. 1962. The political theory of possessive individualism. Oxford: Clarendon Press.

McNeilly, Kathryn. 2014. Gendered violence and international human rights: Thinking non-discrimination beyond the sex binary. Feminist Legal Studies 22(3): 263-283.

McRobbie, Angela. 2004. Feminism and the socialist tradition... Undone? Cultural Studies 18(4): 503-522.

Merry, Sally Engle. 2006. Human rights and gender violence: Translating international law into local justice. Oxford: Oxford University Press.

Morsink, Johannes. 1999. The universal declaration of human rights: Origins, drafting and intent. Philadelphia: University of Pennsylvania Press.

Mouffe, Chantal. 2005a. On the political. London: Routledge.

Mouffe, Chantal. 2005b. The return of the political. London: Verso.

Moyn, Samuel. 2012. The last utopia: Human rights in history Cambridge. Cambridge: Harvard University Press.

Mutua, Maku. 1995. The ideology of human rights. Virginia Journal of International Law 36: 588-657.

Norval, Aletta. 2006. Theorising hegemony: Between deconstruction and psychoanalysis. In Radical democracy: Politics between abundance and lack, ed. Lars Tønder, and Lasse Thomassen, 86-102. Manchester: Manchester University Press.

Norval, Aletta. 2007. Aversive democracy. Cambridge: Cambridge University Press.

Otto, Dianne. 2013. International human rights law: Towards rethinking sex/gender dualism. In The Ashgate research companion to feminist legal theory, ed. Margaret Davies, and Vanessa Munro, 197-216. Farnham: Ashgate.

Peters, Julie, and Andrea Wolper (eds.). 1995. Women's rights as human rights: International feminist perspectives. New York: Routledge.

Rancière, Jacques. 2004a. Disagreement: Politics and philosophy. Minneapolis: University of Minnesota Press.

Rancière, Jacques. 2004b. Who is the subject of the rights of man? The South Atlantic Quarterly 103(2/3): 297-310.

Rancière, Jacques. 2006. Hatred of democracy. London: Verso.

Schippers, Birgit. 2008. Judith Butler, radical democracy and micro-politics. In The politics of radical democracy, ed. Adrian Little, and Moya Lloyd, 73-91. Edinburgh: Edinburgh University Press.

Shapiro, Ian. 1989. The evolution of rights in liberal theory. Cambridge: Cambridge University Press.

Sokhi-Bulley, Bal. 2012. Human rights as technologies of the self: Creating the European governmentable subject of rights. In Re-reading Foucault: On law, power and rights, ed. Ben Golder, 229-247. London: Routledge.

Thomassen, Lasee. 2010. Radical democracy. In After poststructuralism: Transitions and transformations, ed. Rosi Braidotti, 169-186. New York: Routledge.

Wall, Illan Rua. 2012. Human rights and constituent power: Without model or warranty. London: Routledge.

Zigon, Jarrett. 2014. Maintaining the 'truth': Performativity, human rights, and the limitations on politics, Theory \& Event, 17(3): http://muse.jhu.edu/article/553385. Accessed May 7, 2015.

Zivi, Karen. 2012. Making rights claims: A practice of democratic citizenship. Oxford: Oxford University Press. 